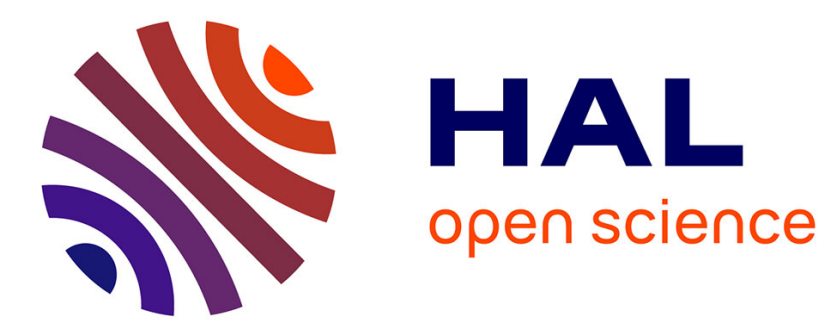

\title{
Biofiltration of high concentration of H2S in waste air under extreme acidic conditions
}

Mouna Ben Jaber, Annabelle Couvert, Abdeltif Amrane, Franck Rouxel, Pierre Le Cloirec, Eric Dumont

\section{- To cite this version:}

Mouna Ben Jaber, Annabelle Couvert, Abdeltif Amrane, Franck Rouxel, Pierre Le Cloirec, et al.. Biofiltration of high concentration of $\mathrm{H} 2 \mathrm{~S}$ in waste air under extreme acidic conditions. New Biotechnology, 2016, 33 (1), pp.136-143. 10.1016/j.nbt.2015.09.008 . hal-01216300

HAL Id: hal-01216300 https://hal-univ-rennes1.archives-ouvertes.fr/hal-01216300

Submitted on 19 Jan 2016

HAL is a multi-disciplinary open access archive for the deposit and dissemination of scientific research documents, whether they are published or not. The documents may come from teaching and research institutions in France or abroad, or from public or private research centers.
L'archive ouverte pluridisciplinaire HAL, est destinée au dépôt et à la diffusion de documents scientifiques de niveau recherche, publiés ou non, émanant des établissements d'enseignement et de recherche français ou étrangers, des laboratoires publics ou privés. 


\section{Highlights}

$\mathrm{H}_{2} \mathrm{~S}$ biofiltration was carried out under extreme acidic conditions

Expanded schist topped with a nutritional material UP20 was used as packing material A maximum elimination capacity of $24.7 \mathrm{~g} \mathrm{~m}^{-3} \mathrm{~h}^{-1}$ was recorded $\left(\mathrm{H}_{2} \mathrm{~S}\right.$ up to $\left.250 \mathrm{ppmv}\right)$ Watering was efficient to restrict acidification and improve biofilter performance

Satisfactory $\mathrm{H}_{2} \mathrm{~S}$ removal was achieved through the combination of schist and UP20 


\title{
Biofiltration of high concentration of $\mathrm{H}_{2} \mathrm{~S}$ in waste air under extreme acidic conditions
}

\section{Mouna BEN JABER, ${ }^{\mathrm{a}, \mathrm{b})}$ Annabelle COUVERT, ${ }^{\mathrm{a}, \mathrm{b})}$ Abdeltif AMRANE, ${ }^{\mathrm{a}, \mathrm{b}}$ Franck ROUXEL, ${ }^{\text {c) }}$ Pierre LE CLOIREC ${ }^{\mathrm{a}, \mathrm{b})}$ Eric DUMONT, ${ }^{\mathrm{d}}{ }^{*}$}

a) Ecole Nationale Supérieure de Chimie de Rennes, CNRS, UMR 6226, 11 Allée de Beaulieu, CS 50837, 35708 Rennes Cedex 7, France

${ }^{b)}$ Université européenne de Bretagne, 5 Boulevard Laënnec, 35000 Rennes, France

c) TC'Plastic, Rue Benjamin Franklin 44160 Pont-Château, France

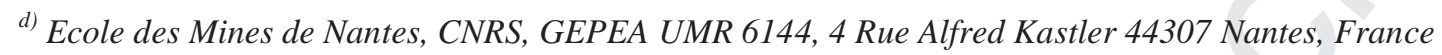

* Corresponding author: eric.dumont@mines-nantes.fr

Tel: +33 (0)2 518582 66; fax: +33 (0)2 51858299

\begin{abstract}
Removal of high concentrations of hydrogen sulfide using a biofilter packed with expanded schist under extreme acidic conditions was performed. The impact of various parameters such as $\mathrm{H}_{2} \mathrm{~S}$ concentration, $\mathrm{pH}$ changes and sulfate accumulation on the performances of the process was evaluated. Elimination efficiency decreased when the $\mathrm{pH}$ was lower than 1 and

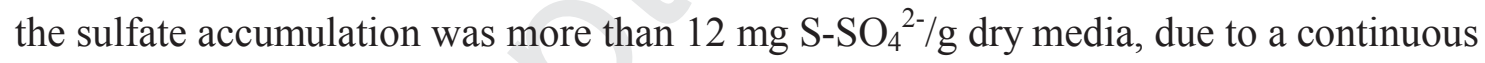
overloading by high $\mathrm{H}_{2} \mathrm{~S}$ concentrations. The influence of these parameters on the degradation of $\mathrm{H}_{2} \mathrm{~S}$ was clearly underlined, showing the need for their control, performed through an increase of watering flow rate. A maximum elimination capacity $\left(\mathrm{EC}_{\max }\right)$ of $24.7 \mathrm{~g} \mathrm{~m}^{-3} \mathrm{~h}^{-1}$ was recorded. As a result, expanded schist represents an interesting packing material to remove high $\mathrm{H}_{2} \mathrm{~S}$ concentration up to 360 ppmv with low pressure drops. In addition, experimental data were fitted using both Michaelis-Menten and Haldane models, showing that the Haldane model described more accurately experimental data since the inhibitory effect of $\mathrm{H}_{2} \mathrm{~S}$ was taken into account.
\end{abstract}

Key words: Biofiltration; Hydrogen sulfide; Sulfate accumulation; pH; Gas treatment; Pressure drop. 


\section{Introduction}

Hydrogen sulfide is one of the main malodorous compounds present in waste gases. It can be produced by several industrial processes such as petroleum refining, wastewater treatment, food processing and paper manufacturing [1]. Hydrogen sulfide is an extremely toxic pollutant which damage human health, corrodes equipment and form poisonous sulfur dioxide (SO2) during its oxidation. Due to its adverse effects to both humans, environment and installation, regulations to control air pollutants are becoming more and more stringent.

Processes used to remove $\mathrm{H}_{2} \mathrm{~S}$ from waste gas streams involve either physical treatment or chemical oxidation. Some methods require chemicals, large investment and operational costs (e.g. high pressures, high temperatures, substantial energy). In addition, these methods are less effective and more expensive for treating $\mathrm{H}_{2} \mathrm{~S}$ in waste gas streams. To overcome these difficulties, biological treatment processes can often serve as suitable alternatives to physicochemical systems. Biofiltration appears to be an attractive technology owing to its high efficiency, cost effectiveness, low energy consumption and environmental acceptability. Although $\mathrm{H}_{2} \mathrm{~S}$ biofiltration has been extensively studied [2-7], only few studies devoted to the treatment of high $\mathrm{H}_{2} \mathrm{~S}$ concentrations in air under extreme acidic conditions were carried out $[8,9]$.

Biofiltration is based on the capacity of some microorganisms to transform contaminants. In biofilm, pollutants are absorbed from a gas to an aqueous phase where microbial attack occurs. In the case of the hydrogen sulfide biodegradation, the metabolites are mainly sulfate and sulfur solid by sulfide oxidizing bacteria (SOB) namely Thiobacillus sp. The following overall biological reactions [9] can be expressed by Eqs $(1,2)$ :

$$
\begin{aligned}
& 2 \mathrm{HS}^{-}+\mathrm{O}_{2} \rightarrow 2 \mathrm{~S}^{\circ}+2 \mathrm{OH}^{-} \\
& 2 \mathrm{~S}^{\circ}+3 \mathrm{O}_{2} \rightarrow 2 \mathrm{SO}_{4}^{2-}+2 \mathrm{H}^{+}
\end{aligned}
$$

Depending on oxygen rate, hydrogen sulfide is converted to elemental sulfur $\left(\mathrm{S}^{0}\right)$ or sulfate $\left(\mathrm{SO}_{4}{ }^{2-}\right)$. In oxygen-limited environments, oxidation may proceed only to elemental sulfur. Consequently, the biofilter bed becomes yellow and clogged over time due to the accumulation of $\mathrm{S}^{0}$. However, in air, oxygen is abundant, and most of the $\mathrm{H}_{2} \mathrm{~S}$ is converted 
into sulfate, which lead to media acidification. Sulfate accumulation and $\mathrm{pH}$ drop can inhibit the microbial activity and can lead to a decrease in the performances of the biofilter [10].

Biofilter performances can be governed by the properties and the characteristics of the packing material such as porosity, water retention capacity, surface area, density and buffer capacity. Various types of media have been used such as organic, inorganic and synthetic. Organic materials used in biofilters include pine bark, peat, compost and soil [5,11-14]. These media have been widely used owing to their low prices, their porosity and the diversity of microbial flora. However, watering the biofilter to maintain bed's humidity leads to bed compaction. As a result, pressure drops increase and the purification performances decrease. Hence, the use of inorganic materials seems be favorable because of their excellent mechanical properties which can limit these pressure drops even during a long operating period [15]. The inorganic materials used include lava rocks [16,17] and expanded schist $[6,7,15]$. Generally, these packing materials have to be inoculated with sludge from wastewater treatment plants containing various non-specific microbial communities which enhance the performance of the biofilter [18-20]. In addition, nutrient equilibrium play an important role in the microbial growth. Generally, in order to provide nutrients to microorganisms, biofilters are sprinkled by a nutritive solution. Synthetic nutritional materials as BIOSORBENS ${ }^{\mathrm{TM}}$ (consisting of hydrophilic mineral cores coated with hydrophobic sorption material) [21] or UP20 [4] were also manufactured. This material makes the addition of nutritive solutions unnecessary. Recent studies on laboratory-scale biofilters have highlighted that expanded schist as packing material completed with UP20 is suitable for $\mathrm{H}_{2} \mathrm{~S}$ biofiltration in terms of removal efficiency $[6,15,22]$.

Biofiltration was widely used to remove low concentration of $\mathrm{H}_{2} \mathrm{~S}$ from air. However, only few studies focused on the efficiency of this process facing high concentration of $\mathrm{H}_{2} \mathrm{~S}$. The accumulation of sulfuric acid generated by $\mathrm{H}_{2} \mathrm{~S}$ oxidation leads to a significant acidification of biofilter bed. The $\mathrm{pH}$ decreases when the system is overloaded by high $\mathrm{H}_{2} \mathrm{~S}$ input and can be considered as an issue for practical applications.

The purpose of this study was to evaluate the performances of a biofilter packed with expanded schist particles under high concentrations of hydrogen sulfide in air and extreme acidic conditions. A significant effort was developed to study the impact of $\mathrm{pH}$ changes and sulfate accumulation. Moreover, the kinetic aspects of biodegradation were described by fitting the experimental data with Michaelis-Menten and Haldane models. 


\section{Materials and methods}

\subsection{Filter media}

Expanded schist used as the microorganism support material is an inorganic support produced in Mayenne (France) by the thermal expansion reaction of schist (Figure 1). The composition of this media (Table 1) was determined using an Energy Dispersive X-ray Fluorescence Spectometer (EDX-800HS, shimadzu Company). Expanded schist has been chosen for its good mechanical properties (Table 2). The structural porosity and the specific surface area were measured by a mercury porosimiter Micromeritics AutoPore IV 9500. Using inorganic packing material like expanded schist, pressure drops associated to bed debasement and compaction are low. Pressure drop values reported by the literature range from 10 to $80 \mathrm{~Pa} \mathrm{~m}^{-}$ ${ }^{1}$ for superficial velocity varying between 89 and $229 \mathrm{~m} \mathrm{~h}^{-1}$ [15].

Table 1

Table 2

\subsection{Nutrients}

Inorganic materials provide an interesting physical support for bacteria, but generally it does not ensure enough nutrient content. A cylindrical-shaped extruded material called UP20 was produced to provide nutrient equilibrium to microorganisms (Figure 1). This specific material, whose formulation has been described in previous works [4], has been successfully used in several studies for $\mathrm{H}_{2} \mathrm{~S}$ treatment $[3,4,6,22]$. UP20 contains urea phosphate $\left(\mathrm{CH}_{4} \mathrm{~N}_{2} \mathrm{O}, \mathrm{H}_{3} \mathrm{PO}_{4}\right)$, calcium carbonate $\left(\mathrm{CaCO}_{3}\right)(\mathrm{C} / \mathrm{N} / \mathrm{P}$ molar ratio: $100 / 10 / 5)$ and an organic binder (ELOTEX ST2400; 20\% in mass) from Elotex Company. This material provides both nutrients and a buffering effect for biofilm and water hold-up.

Figure 1: Photography of UP20 (left) and expanded schist (right).

\subsection{Experimental Set-up}


The laboratory-scale system used in this work is shown in Figure 2. It consisted of a PVC column with an internal diameter of $300 \mathrm{~mm}$. Biofilter was packed with expanded schist $(1 \mathrm{~m}$ height; volume $70 \mathrm{~L}$ ) topped with UP20 (2 cm corresponding to $1.4 \mathrm{~L}$ ). It was inoculated with $5 \mathrm{~L}$ of a diluted solution of activated sludge (about $50 \mathrm{mg} \mathrm{DSS} / \mathrm{L}$ ) from a domestic wastewater treatment plant (Tougas, Nantes, France).

The air flow is generated using a regulated fan (FMV frequency controller 2107, Leroy Somer Angoulême, France). It passes through a humidification High Density Polyethylene cylinder $($ HDPE) column packed with Hiflow rings (packing height $=1.50 \mathrm{~m}$ ) of internal diameter of $200 \mathrm{~mm} . \mathrm{H}_{2} \mathrm{~S}$ stream (99.7\% purity), controlled by a mass flow controller (Model 5850S, Brooks Instrument, Hatfield, USA), was diluted in the atmospheric air at the outlet of the humidification column. The polluted air was then introduced at the bottom of the biofilter. Biofilter watering was implemented to maintain the humidity of the packing material.

\section{Figure 2: Experimental pilot-scale biofilter:}

1 Centrifugal fan, 2 rotameter, 3 humidification column, 4 pump, 5 injection point of $\mathrm{H}_{2} \mathrm{~S}, 6$ biofilter, 7-13 gas sampling ports, 14 leachate outlet, 15 outlet gas.

\subsection{Analytical methods}

The $\mathrm{H}_{2} \mathrm{~S}$ concentration was measured with an Onyx 5220 device (measurement accuracy \pm 1\%) from the Cosma Environment SA Company (Passy, France) The analyzer was calibrated daily using a standard gas (400 ppmv). The eight points for gas sampling were located at the inlet and at the outlet of the biofilter, and at 10,30, 50, 70,90 and $100 \mathrm{~cm}$ from the biofilter bottom respectively (Figure 2). The $\mathrm{pH}$ of leachate was measured by a $\mathrm{pH}$ electrode (Consort) connected to a multi-parameter analyzer Consort C-561 (measurement accuracy $0.2 \% \pm 1$ digit).

Sulfate determination was carried out by the turbidimetric method as described in Standard methods for the examination of water and wastewater [23]. Samples for the sulfate determination were taken periodically from the leachate.

\subsection{Operating conditions}

The polluted air flow rate was $4 \mathrm{~m}^{3} \mathrm{~h}^{-1}$ corresponding to an Empty Bed Retention Time (EBRT) of 63 s. Periodical watering (once a day) was used to maintain the humidity of the 
bed material and to avoid sulfate accumulation. It was provided at a constant flow of $0.8 \mathrm{~L}$ $\min ^{-1}$ during 15 minutes corresponding to a tap water flow rate $\left(\mathrm{Q}_{\mathrm{Liq}}\right)$ of $12 \mathrm{~L} \mathrm{day}^{-1}$. The operating conditions applied during this study are reported in Table 3.

Table 3: Operating conditions.

The removal efficiency (RE), the loading rate (LR) and the elimination capacity (EC) of the biofilter were calculated as follows:

$$
\begin{gathered}
\operatorname{RE}(\%)=\frac{\left(\mathbf{C}_{\text {in }}-\mathbf{C}_{\text {out }}\right)}{\mathbf{C}_{\text {in }}} \times 100 \\
\operatorname{LR}\left(\mathrm{g} \mathrm{m}^{-3} \mathrm{~h}^{-1}\right)=\frac{\mathbf{Q}}{V} \mathbf{C}_{\text {in }} \\
\operatorname{EC~}\left(\mathrm{g} \mathrm{m}^{-3} \mathrm{~h}^{-1}\right)=\frac{\mathbf{Q}}{V}\left(\mathbf{C}_{\text {in }}-\mathbf{C}_{\text {out }}\right)
\end{gathered}
$$

Where $\mathrm{C}_{\mathrm{in}}$ and $\mathrm{C}_{\text {out }}$ are the inlet and outlet concentrations $\left(\mathrm{mg} \mathrm{m}^{-3}\right)$ respectively, $\mathrm{Q}$ is the gas flow rate $\left(\mathrm{m}^{3} \mathrm{~h}^{-1}\right)$ and $\mathrm{V}$ is the bed volume of packing material $\left(\mathrm{m}^{3}\right)$.

\section{Results and discussion}

\subsection{Effect of increasing $\mathrm{H}_{2} \mathrm{~S}$ concentrations}

The impact of increasing $\mathrm{H}_{2} \mathrm{~S}$ concentrations (from 40 to $360 \mathrm{ppmv}$ ) on the biofilter performances is shown in Figure 3. The acclimation period for the microbial population was quite short. $\mathrm{H}_{2} \mathrm{~S}$ was totally removed from the $3^{\text {rd }}$ day $(\mathrm{RE}>99 \%)$. Such observation can be explained by the bacterial inoculum and the presence of UP20 which can react (acid - base) with the polluted gas [24]. For $\mathrm{H}_{2} \mathrm{~S}$ concentrations up to 250 ppmv, a $100 \% \mathrm{RE}$ was recorded proving the ability of the expanded schist to be used for biofiltration. As shown in Figure 3, the performance efficiency started decreasing from the $143^{\text {th }}$ day. This decrease was significantly pronounced, from the $172^{\text {th }}$ day, when $\mathrm{H}_{2} \mathrm{~S}$ concentration was very high (ranging from 250 to $360 \mathrm{ppmv}$ ). It can be due to a direct inhibitory effect on the metabolism of some microorganisms. Indeed, when the system is continuously overloaded by high $\mathrm{H}_{2} \mathrm{~S}$ input, 
$\mathrm{H}_{2} \mathrm{SO}_{4}$ is produced continuously as a by-product of the $\mathrm{H}_{2} \mathrm{~S}$ biological oxidation (Eq.2), which leads to biofilter acidification and sulfate accumulation. During this period, the $\mathrm{pH}$ dropped to 0.5 (Figure 3 ). The decrease of $\mathrm{pH}$ and the sulfate accumulation probably can lead to the deterioration of biofilter performances [10,25]. Sulfur oxidizing bacteria can live in environments with $\mathrm{pH}$ ranging between 1 and 8 [10]. The optimal $\mathrm{pH}$ is between 6 and 8 [1], but $\mathrm{H}_{2} \mathrm{~S}$ can also be oxidized by microorganisms like Thiobacillus and Acidithiobacillus at very acidic $\mathrm{pH}$. Rodriguez et al. [26] found a $\mathrm{H}_{2} \mathrm{~S}$ removal efficiency of $95 \%$ at a $\mathrm{pH}$ between 4 and 7, and a removal efficiency of $87 \%$ at a pH between 2 and 3. Others authors observed a maximum $\mathrm{H}_{2} \mathrm{~S}$ removal at a $\mathrm{pH}$ value of $3.2[10,16]$. They mentioned that a low $\mathrm{pH}$ can significantly inhibit the biological activity of the microorganisms; therefore the removal efficiency decreases progressively. Soupramanien et al. [27], who measured a complete $\mathrm{H}_{2} \mathrm{~S}$ degradation at $\mathrm{pH}=1$, indicated that the $\mathrm{pH}$ value strongly influences the diversity of the bacterial community. However, only few data are available for $\mathrm{pH}$ lower than 1 .

Figure 3: Removal efficiency of $\mathrm{H}_{2} \mathrm{~S}$ and $\mathrm{pH}$ changes in biofilter $\left(\mathrm{H}_{2} \mathrm{~S}\right.$ concentrations from 40 to 360 ppmv; EBRT=63s).

\subsection{Effect of sulfate accumulation and $\mathrm{pH}$ changes on $\mathrm{H}_{2} \mathrm{~S}$ removal}

Due to the production of sulfuric acid, the effect of sulfate accumulation on $\mathrm{H}_{2} \mathrm{~S}$ removal was evaluated. On the $56^{\text {th }}$ day, the sulfate concentration was $12.7 \mathrm{mg} \mathrm{S}-\mathrm{SO}_{4}{ }^{2-} / \mathrm{g}$ dry media and $\mathrm{H}_{2} \mathrm{~S}$ was completely removed in the biofilter. When the sulfate concentration was less than 24 ${\mathrm{mg} \mathrm{S}-\mathrm{SO}_{4}}^{2-} / \mathrm{g}$ dry media, the removal efficiency was above $90 \%$. A significant decrease of the removal efficiency, to $78 \%$, was underlined when the sulfate content was close to $49 \mathrm{mg}$ S$\mathrm{SO}_{4}{ }^{2-} / \mathrm{g}$ dry media (Figure 4). In the presence of large amounts of oxygen, sulfate was produced from the bio-oxidation of hydrogen sulfide by the sulfide oxidizing bacteria. Sulfate is a water soluble compound which can have a negative effect on the microbial activity. Yang and Allen [10] suggested that sulfate concentration of $25 \mathrm{mg} \mathrm{S}-\mathrm{SO}_{4}{ }^{2-} / \mathrm{g}$ dry media was a critical level for the microbial activity. Above this level, an inhibiting effect on $\mathrm{H}_{2} \mathrm{~S}$ removal could be observed. Morgan-Sagastume and Noyola [28] suggested to work at a sulfate concentration less than $12 \mathrm{mg} \mathrm{S}-\mathrm{SO}_{4}{ }^{2-} / \mathrm{g}$ dry media which is consequently lower than the critical level proposed by Yang and Allen [10]. To avoid $\mathrm{SO}_{4}{ }^{2-}$ accumulation, Ramírez-Sáenz et al. [16] suggested periodical water cleaning of the biofilter to limit sulfate concentrations to about $8 \mathrm{mg} \mathrm{S}-\mathrm{SO}_{4}{ }^{2-} / \mathrm{g}$ dry media. According to the present study and measurements, the 
sulfate accumulation influences significantly the degradation of $\mathrm{H}_{2} \mathrm{~S}$ for concentrations up to $12 \mathrm{mg} \mathrm{S}-\mathrm{SO}_{4}{ }^{2-} / \mathrm{g}$ dry media (Figure 4). As a result, periodical water additions could be carried out to keep sulfate concentration lower than this critical value.

Figure 4: Effect of sulfate accumulation on $\mathrm{H}_{2} \mathrm{~S}$ degradation.

The influence of $\mathrm{pH}$ changes can also be clearly underlined (Figure 3). For $\mathrm{H}_{2} \mathrm{~S}$ concentrations up to $250 \mathrm{ppmv}$, the $\mathrm{pH}$ was 1.2 and the removal efficiency was kept constant until the $161^{\text {th }}$ day $(96 \%)$. It has to be noted that the layer of UP20 $(2 \mathrm{~cm})$ located above the packing was not enough to provide a buffering effect for biofilter especially at very high $\mathrm{H}_{2} \mathrm{~S}$ concentration (above $250 \mathrm{ppmv}$ ). Therefore, increasing the layer thickness of UP20 to treat high concentrations of $\mathrm{H}_{2} \mathrm{~S}$ could be considered. However, a specific study should be carried out to investigate this point. Once $\mathrm{pH}$ dropped to values less than 1 , the performance decreased significantly. Hence, the increase in the $\mathrm{H}_{2} \mathrm{~S}$ concentration (until 360 ppmv; Phase 6) led to a decrease in the $\mathrm{pH}$ value (around 0.5 ) and concomitantly a decrease in the removal efficiency (78\%). From the $200^{\text {th }}$ day, a decrease in $\mathrm{H}_{2} \mathrm{~S}$ concentration to $250 \mathrm{ppmv}$ was applied but the $\mathrm{pH}$ was still less than 0.5 . With the same concentration (250 ppmv) the removal efficiency decreased from $92-100 \%$ (Phase 5) to $73-80 \%$ (Phase 7; Figure 3). In order to decrease sulfate concentration and to raise the $\mathrm{pH}$ value in the packing material, the watering flow rate $\left(\mathrm{Q}_{\mathrm{Liq}}\right)$ was increased from $12 \mathrm{~L} \mathrm{day}^{-1}\left(0.007 \mathrm{~m}^{3}\right.$ water $\mathrm{m}^{-3}$ bed $\left.\mathrm{h}^{-1}\right)$ to $120 \mathrm{~L}_{\text {day }}$ ${ }^{1}\left(0.07 \mathrm{~m}_{\text {water }}^{3} \mathrm{~m}^{-3}\right.$ bed $\left.\mathrm{h}^{-1}\right)$ from the $234^{\text {th }}$ day, as pointed out by the arrow in the Phase 7 (Figure 3 ). The increasing of the watering flow rate allowed to maintain the $\mathrm{pH}$ value greater than 1 , and then the removal efficiency was improved (Figure 5). For $\mathrm{H}_{2} \mathrm{~S}$ concentration of 250 ppmv, on the $224^{\text {th }}$ day, the $\mathrm{pH}$ was 0.2 and the removal efficiency was $73 \%$, whereas, on the $242^{\text {th }}$ day, the $\mathrm{pH}$ was 1.8 and the removal efficiency increased to achieve 95\% (Figure 3 ). Consequently, it clearly appeared that an efficient $\mathrm{H}_{2} \mathrm{~S}$ biofiltration required to work at a $\mathrm{pH}$ greater than 1 . In terms of maximal elimination capacity, an improvement of around $10 \%$ was observed $\left(\mathrm{EC}_{\max }=24.7 \mathrm{~g} \mathrm{~m}^{-3} \mathrm{~h}^{-1}\right)$.

Figure 5: Impact of the increasing of watering flow rate from $12 \mathrm{~L} \mathrm{day}^{-1}$ to $120 \mathrm{~L} \mathrm{day}^{-1}$ on the removal efficiency $(\mathrm{EBRT}=63 \mathrm{~s})$. 


\subsection{Pressure drop}

The pressure drop was measured daily between the ports located at 10 and $100 \mathrm{~cm}$ from the bottom of the biofilter. Figure 6 shows that $\Delta \mathrm{P}$ ranged from $3 \mathrm{~Pa} \mathrm{~m}^{-1}\left(0.03 \mathrm{~cm}_{\mathrm{H} 2 \mathrm{O}}{ }^{-1}\right)$ to 94 $\mathrm{Pa} \mathrm{m}^{-1}\left(0.96 \mathrm{~cm}_{\mathrm{H} 2 \mathrm{O}} \mathrm{m}^{-1}\right)$ for gas velocities varying between 56 and $565 \mathrm{~m} \mathrm{~h}^{-1}$. These values are comparable to those recorded by Dumont et al. [3] using pozzolan media (5-100 $\mathrm{Pa} \mathrm{m}^{-1}$ ) for gas velocities between 65 and $520 \mathrm{~m} \mathrm{~h}^{-1}$, but lower than those obtained using organic packing materials in other studies. For instance, pressure drops between 500 and $1000 \mathrm{~Pa} \mathrm{~m}^{-1}$ were obtained in a bed consisting of compost operating at gas velocities between 72 and $1000 \mathrm{~m} \mathrm{~h}^{-1}$ [10]. For pine bark, $\Delta \mathrm{P}$ varied from 15 to $388 \mathrm{~Pa} \mathrm{~m}^{-1}$ at gas velocities ranging between 65 and $520 \mathrm{~m} \mathrm{~h}^{-1}$ [3]. After 220 days of operation, $\Delta \mathrm{P}$ increased to values between 4 and $105 \mathrm{~Pa} \mathrm{~m}^{-1}$ for the same velocity range. The increase of pressure drop can be related to the biofilm growth, especially when the system was overloaded by high $\mathrm{H}_{2} \mathrm{~S}$ concentrations (250 - 360 ppmv); an increase of $12 \%$ of the pressure drop was then observed. This increase can also be due to the formation of elemental sulfur $\left(S^{0}\right)$ which partially clogs the packing material. This interpretation was confirmed by observing some yellow deposits in the biofilter after a long period of operation. Nonetheless, these low values showed that there was no compaction of the bed during the long operation period, which indicated that expanded schist is an interesting material for biofiltration in terms of bed mechanical stability.

Figure 6: Pressure drop measurements in the biofilter for gas velocities varying between 56 and $565 \mathrm{~m} \mathrm{~h}^{-1}$.

\subsection{Modeling performances by Michaelis-Menten and Haldane equations}

In order to predict the performance of the biofilter, efforts were directed toward modeling. Many models are available in the literature to describe the pollutant biodegradation kinetics [29]. The elimination capacity (EC) vs pollutant concentration can be adequately described by a Michaelis-Menten model (Eq 6) [6,30,31]:

$$
\mathrm{EC}=\frac{\mathrm{EC}_{\max } C_{\mathrm{ln}}}{\mathrm{K}_{\mathrm{g}}+\mathrm{C}_{\mathrm{ln}}}
$$

Where

$\mathrm{EC}_{\max }$ : Maximal elimination capacity $\left(\mathrm{g} \mathrm{m}^{-3} \mathrm{~h}^{-1}\right)$ 
$\mathrm{C}_{\mathrm{ln}}$ : Logarthimic average of the inlet and outlet concentrations of pollutants in the gas phase $\left(\mathrm{g} \mathrm{m}^{-3}\right)$

$\mathrm{K}_{\mathrm{s}}$ : Saturation constant $\left(\mathrm{g} \mathrm{m}^{-3}\right)$

$\mathrm{EC}_{\max }$ and $\mathrm{K}_{\mathrm{s}}$ are calculated by rearranging Eq. 6 to take the form of the Lineweaver-Burk equation below (Eq 7):

$$
\frac{1}{E C}=\frac{K_{s}}{E C_{\max } C_{l n}}+\frac{1}{E C_{\max }}
$$

In the case of biomass inhibition due to high $\mathrm{H}_{2} \mathrm{~S}$ concentrations, the Haldane model, including an inhibition term, can be used $[6,32,33]$. The elimination capacity is then calculated by Eq (8):

$$
\mathrm{EC}=\frac{E C^{*} \mathrm{C}_{\mathrm{ln}}}{\mathrm{K}_{\mathrm{g}}^{\prime}+\mathrm{C}_{\mathrm{ln}}+\left(\mathrm{C}_{\mathrm{ln}}^{2} / \mathrm{K}_{\mathrm{I}}\right)}
$$

Where

$\mathrm{EC}^{*}$ : Maximal elimination capacity in the absence of inhibition $\left(\mathrm{g} \mathrm{m}^{-3} \mathrm{~h}^{-1}\right)$

$\mathbf{K}_{s}^{\prime}:$ Saturation constant $\left(\mathrm{g} \mathrm{m}^{-3}\right)$

$\mathrm{K}_{\mathrm{I}}$ : Inhibition constant $\left(\mathrm{g} \mathrm{m}^{-3}\right)$

Haldane's model constants $\left(\mathbf{E C}^{*}, \mathbf{K}_{\mathbf{s}}^{\prime}, \mathrm{K}_{\mathrm{I}}\right)$ are calculated from the regression of Eq.8, rearranged as follows (Eq 9):

$$
\frac{\mathrm{C}_{\ln }}{\mathrm{EC}}=\frac{\mathbf{K}_{3}^{\prime}}{\mathrm{EC}^{*}}+\frac{\mathrm{C}_{\ln }}{\mathrm{EC}^{*}}+\frac{\mathrm{C}_{\mathrm{ln}}^{2}}{\mathrm{EC}^{*} \mathbf{K}_{\mathbf{l}}}
$$

In this case, $\mathrm{EC}_{\max }$ can be calculated by following the mathematical analysis reported by Sologar et al. [34] (Eq 10):

$$
\mathrm{EC}_{\max }=\frac{\mathrm{EC}^{*}}{1+2 \sqrt{\left(K_{\mathrm{g}}^{\prime} / \mathrm{K}_{\mathrm{I}}\right)}}
$$

Figure 7 shows $\mathrm{EC}$ versus $\mathrm{C}_{\mathrm{ln}}$ for the biofilter at a constant EBRT of $63 \mathrm{~s}$. Biodegradation kinetics values determined from the Michaelis-Menten and Haldane models are reported in Table 4. 
Table 4: Biodegradation kinetics values determined from the Michaelis-Menten and Haldane models

As observed in Figure 7, the experimental EC for $\mathrm{H}_{2} \mathrm{~S}$ was slightly better fitted by the Haldane model, certainly because of the inhibitory effect of $\mathrm{H}_{2} \mathrm{~S}$. The experimental $\mathrm{EC}_{\max }$ for $\mathrm{H}_{2} \mathrm{~S}$ was $22.6 \mathrm{~g} \mathrm{~m}^{-3} \mathrm{~h}^{-1}$, while the $\mathrm{EC}_{\max }$ estimated with the Michaelis-Menten model and the Haldane model were 28.6 and $22.7 \mathrm{~g} \mathrm{~m}^{-3} \mathrm{~h}^{-1}$ respectively. A significant inhibitory effect of $\mathrm{H}_{2} \mathrm{~S}$ on the microbial activity was therefore underlined, since the maximal elimination capacity in the absence of inhibition $\left(\mathrm{EC}^{*}\right)$ was higher than the maximal elimination capacity which takes into account inhibition effect (Table 4). The maximal elimination capacity value obtained is higher than those reported with some other packing materials. At an EBRT of $57 \mathrm{~s}$, maximal removal capacities of 14 and $15 \mathrm{~g} \mathrm{~m}^{-3} \mathrm{~h}^{-1}$ were obtained with a pine bark and pozzolan/UP20, respectively [3]. At an EBRT of $51 \mathrm{~s}$, an $\mathrm{EC}_{\max }$ of $8 \mathrm{~g} \mathrm{~m}^{-3} \mathrm{~h}^{-1}$ was also achieved using pall rings as packing material [35]. Comparing biodegradation kinetics values $\left(\mathrm{K}_{\mathrm{s}}, \mathbf{K}_{s}^{\prime}, \mathrm{K}_{\mathrm{I}}\right)$ with previous work data seems difficult because they depend mainly on EBRT as demonstrated by Romero Hernandez et al. [6]. Nonetheless, it can be pointed out that the $\mathrm{K}_{\mathrm{s}}$ value obtained for expanded schist topped with UP20 was of the order of magnitude of the reported value for peat mixed with UP20, which is a classical and an efficient packing material for $\mathrm{H}_{2} \mathrm{~S}$ biofiltration $\left(\mathrm{K}_{\mathrm{S}}=0.089 \mathrm{~g} \mathrm{~m}^{-3}\right.$ at an EBRT of $\left.57 \mathrm{~s}\right)$ [2].

To summarize, these results demonstrated that biofilters filled with expanded schist coupled with UP20 could be suitable for industrial applications. The good mechanical behavior of the expanded schist (low pressure drop) and the ability to oxidize $\mathrm{H}_{2} \mathrm{~S}$ under extreme acidic conditions for a long period confirm the advantage of using expanded schist coupled with UP20 for long-term $\mathrm{H}_{2} \mathrm{~S}$ biofiltration. The influence of parameters as watering rate and amount of UP20 could be deeply investigated in order to determine the better biofilter performances according to the EBRT used.

Figure 7: Elimination capacity as a function of the logarithmic average of inlet and outlet concentrations in gas phase of the biofilter $\left(\mathrm{C}_{\mathrm{ln}}\right)$ for $\mathrm{H}_{2} \mathrm{~S}$ (Experimental points, MichaelisMenten and Haldane models) $\left(\mathrm{EBRT}=63 \mathrm{~s} ; \mathrm{C}_{\mathrm{ln}}\right.$ between 0.03 and $\left.0.46 \mathrm{~g} \mathrm{~m}^{-3}\right)$.

\section{Conclusion}


The biological removal of $\mathrm{H}_{2} \mathrm{~S}$ in waste gas was carried out under extreme acidic conditions using a biofilter packed with expanded schist and topped with a layer of a synthetic nutritional material (UP20) at a constant EBRT of $63 \mathrm{~s}$. It has been shown that the combination of expanded schist and UP20 can be successfully used to remove high concentration of $\mathrm{H}_{2} \mathrm{~S}$, up to 360 ppmv. Pressure drops were very low (around $4 \mathrm{~Pa} \mathrm{~m}^{-1}$ after 220 days of operation). As expected, no bed compaction was observed during the running period due to a mechanical stability of the schist material. However, if the biofilter was continuously overloaded by high $\mathrm{H}_{2} \mathrm{~S}$ concentration, the major production of the oxidation reaction was sulfuric acid. The sulfate accumulation in the biofilter bed and the significant $\mathrm{pH}$ decrease $(\mathrm{pH}<1)$ led to a significant decrease in the performances of the process. As a result, it was required to increase the watering flow rate up to $120 \mathrm{~L} \mathrm{~h}^{-1}$ in order to avoid sulfate accumulation and to maintain the $\mathrm{pH}>1$. In such conditions, a removal efficiency higher than $95 \%$ was achieved for $\mathrm{H}_{2} \mathrm{~S}$ concentration up to $250 \mathrm{ppmv}$, corresponding to a maximum elimination capacity of $24.7 \mathrm{~g} \mathrm{~m}^{-}$ ${ }^{3} \mathrm{~h}^{-1}$.

This study shows that such double layer biofilters (nutrient provider and inorganic packing materials) give interesting performances to remove high concentrations of $\mathrm{H}_{2} \mathrm{~S}$ present in waste gas or air. However, operating conditions such as volumetric load and periodic water addition have to be controlled carefully to avoid a significant level of inhibitory by-products leading to increasing amounts of sulfate and a drastic decrease of $\mathrm{pH}$.

\section{References}

[1] Chung YC, Huang C, Tseng CP. Operation optimization of Thiobacillus thioparus CH11 biofilter for hydrogen sulfide removal. J Biotechnol 1996;52:31-8.

[2] Dumont E, Andrès Y. Evaluation of innovative packing materials for the biodegradation of $\mathrm{H}_{2} \mathrm{~S}$ : a comparative study. J Chem Technol Biotechnol 2010;85:429-34.

[3] Dumont E, Andrès Y, Le Cloirec P, Gaudin F. Evaluation of a new packing material for $\mathrm{H}_{2} \mathrm{~S}$ removed by biofiltration. Biochem Eng J 2008;42:120-7.

[4] Gaudin F, Andres Y, Le Cloirec P. Packing material formulation for odorous emission biofiltration. Chemosphere 2008;70:958-66.

[5] Ben Jaber M, Anet B, Amrane A, Couriol C, Lendormi T, Cloirec PL, et al. Impact of nutrients supply and $\mathrm{pH}$ changes on the elimination of hydrogen sulfide, dimethyl disulfide and ethanethiol by biofiltration. Chem Eng J 2014;258:420-6. 
[6] Romero Hernandez AC, Rodríguez Susa MS, Andrès Y, Dumont E. Steady- and transient-state $\mathrm{H}_{2} \mathrm{~S}$ biofiltration using expanded schist as packing material. New Biotechnol 2013;30:210-8.

[7] Shareefdeen $\mathrm{Z}$. Hydrogen sulfide $\left(\mathrm{H}_{2} \mathrm{~S}\right)$ removal using schist packings in industrial biofilter applications. Korean J Chem Eng 2015;32:15-9.

[8] Laokor M, Techkarnjanaruk S, Rugruam W, Chaiprasert P. Removal of High Strength $\mathrm{H}_{2} \mathrm{~S}$ using Active Sludge Immobilized Biofiltration. Pattaya, Thailand: Proceeding of the 8th International Symposium on Biocontrol and Biotechnology; 2010.

[9] Oyarzún P, Arancibia F, Canales C, Aroca GE. Biofiltration of high concentration of hydrogen sulphide using Thiobacillus thioparus. Process Biochem 2003;39:165-70.

[10] Yang Y, Allen ER. Biofiltration Control of Hydrogen Sulfide 1. Design and Operational Parameters. Air Waste 1994;44:863-8.

[11] Burgess JE, Parsons SA, Stuetz RM. Developments in odour control and waste gas treatment biotechnology: a review. Biotechnol Adv 2001;19:35-63.

[12] Degorce-Dumas JR, Kowal S, Cloirec PL. Microbiological oxidation of hydrogen sulphide in a biofilter. Can J Microbiol 1997;43:264-71.

[13] Kennes C, Thalasso F. Review: Waste gas biotreatment technology. J Chem Technol Biotechnol 1998;72:303-19.

[14] Malhautier L, Gracian C, Roux JC, Fanlo JL, Le Cloirec P. Biological treatment process of air loaded with an ammonia and hydrogen sulfide mixture. Chemosphere 2003;50:145-53.

[15] Dumont E, Ayala Guzman LM, Rodríguez Susa MS, Andrès Y. $\mathrm{H}_{2} \mathrm{~S}$ biofiltration using expanded schist as packing material: performance evaluation and packed-bed tortuosity assessment. J Chem Technol Biotechnol 2012;87:725-31.

[16] Ramírez-Sáenz D, Zarate-Segura PB, Guerrero-Barajas C, García-Peña EI. $\mathrm{H}_{2} \mathrm{~S}$ and volatile fatty acids elimination by biofiltration: Clean-up process for biogas potential use. J Hazard Mater 2009;163:1272-81.

[17] Soreanu G, Béland M, Falletta P, Ventresca B, Seto P. Evaluation of different packing media for anoxic $\mathrm{H}_{2} \mathrm{~S}$ control in biogas. Environ Technol 2009;30:1249-59.

[18] De Arespacochaga N, Valderrama C, Mesa C, Bouchy L, Cortina JL. Biogas biological desulphurisation under extremely acidic conditions for energetic valorisation in Solid Oxide Fuel Cells. Chem Eng J 2014;255:677-85.

[19] Fortuny M, Gamisans X, Deshusses MA, Lafuente J, Casas C, Gabriel D. Operational aspects of the desulfurization process of energy gases mimics in biotrickling filters. Water Res 2011;45:5665-74.

[20] Mannucci A, Munz G, Mori G, Lubello C. Biomass accumulation modelling in a highly loaded biotrickling filter for hydrogen sulphide removal. Chemosphere 2012;88:712-7.

[21] Shareefdeen $Z$, Herner $B$, Webb D, Wilson $S$. Hydrogen sulfide $\left(\mathrm{H}_{2} \mathrm{~S}\right)$ removal in synthetic media biofilters. Environ Prog 2003;22:207-13.

[22] Courtois A, Andrès Y, Dumont É. $\mathrm{H}_{2} \mathrm{~S}$ biofiltration using expanded schist as packing material: influence of packed bed configurations at constant EBRT. J Chem Technol Biotechnol 2015;90:50-6.

[23] American Public Health Association. Standard Methods for the examination of Water and Wastewater. 17th ed. Washington: APHA-AWWA-WPCF; 1989.

[24] Dumont E, Cabral FDS, Le Cloirec P, Andrès Y. Biofiltration using peat and a nutritional synthetic packing material: influence of the packing configuration on $\mathrm{H}_{2} \mathrm{~S}$ removal. Environ Technol 2013;34:1123-9.

[25] Yang Y, Allen ER. Biofiltration Control of Hydrogen Sulfide 2. Kinetics, Biofilter Performance, and Maintenance. Air Waste 1994;44:1315-21. 
[26] Rodriguez G, Dorado AD, Fortuny M, Gabriel D, Gamisans X. Biotrickling filters for biogas sweetening: Oxygen transfer improvement for a reliable operation. Process Saf Environ Prot 2014;92:261-8.

[27] Soupramanien A, Malhautier L, Dumont E, Andrès Y, Rocher J, Fanlo J-L. Biological treatment of a mixture of gaseous sulphur reduced compounds: identification of the total bacterial community's structure. J Chem Technol Biotechnol 2012;87:817-23.

[28] Morgan-Sagastume JM, Noyola A. Hydrogen sulfide removal by compost biofiltration: Effect of mixing the filter media on operational factors. Bioresour Technol 2006;97:1546-53.

[29] Devinny JS, Deshusses MA, Webster TS. Biofiltration for air pollution control. Boca Raton: Lewis Publishers; 1999.

[30] Chung YC, Huang C, Tseng CP. Biological elimination of $\mathrm{H}_{2} \mathrm{~S}$ and $\mathrm{NH}_{3}$ from wastegases by biofilter packed with immobilized heterotrophic bacteria. Chemosphere 2001;43:1043-50.

[31] Hirai M, Ohtake M, Shoda M. Removal kinetics of hydrogen sulfide, methanethiol and dimethyl sulfide by peat biofilters. J Ferment Bioeng 1990;70:334-9.

[32] Avalos Ramirez A, Bénard S, Giroir-Fendler A, Jones JP, Heitz M. Kinetics of microbial growth and biodegradation of methanol and toluene in biofilters and an analysis of the energetic indicators. J Biotechnol 2008;138:88-95.

[33] Gallastegui G, Ávalos Ramirez A, Elías A, Jones JP, Heitz M. Performance and macrokinetic analysis of biofiltration of toluene and p-xylene mixtures in a conventional biofilter packed with inert material. Bioresour Technol 2011;102:7657-65.

[34] Sologar VS, Lu Z, Allen DG. Biofiltration of concentrated mixtures of hydrogen sulfide and methanol. Environ Prog 2003;22:129-36.

[35] Kim JH, Rene ER, Park HS. Biological oxidation of hydrogen sulfide under steady and transient state conditions in an immobilized cell biofilter. Bioresour Technol 2008;99:583-8. 
Figure 1: Photography of UP20 (left) and expanded schist (right).

Figure 2: Experimental pilot-scale biofilter: 1 Centrifugal fan, 2 rotameter, 3 humidification column, 4 pump, 5 injection point of $\mathrm{H}_{2} \mathrm{~S}, \mathbf{6}$ biofilter, 7-13 gas sampling ports, 14 leachate outlet, 15 outlet gas.

Figure 3: Removal efficiency of $\mathrm{H}_{2} \mathrm{~S}$ and $\mathrm{pH}$ changes in biofilter $\left(\mathrm{H}_{2} \mathrm{~S}\right.$ concentrations from 40 to $360 \mathrm{ppmv}$; EBRT=63s).

Figure 4: Effect of sulfate accumulation on $\mathrm{H}_{2} \mathrm{~S}$ degradation.

Figure 5: Impact of the increasing of watering flow rate from $12 \mathrm{~L} /$ day to $120 \mathrm{~L} /$ day on the removal efficiency $(\mathrm{EBRT}=63 \mathrm{~s})$.

Figure 6: Pressure drop measurements in the biofilter for gas velocities varying between 56 and $565 \mathrm{~m} \mathrm{~h}^{-1}$.

Figure 7: Elimination capacity as a function of the logarithmic average of inlet and outlet concentrations in gas phase of the biofilter $\left(\mathrm{C}_{\mathrm{ln}}\right)$ for $\mathrm{H}_{2} \mathrm{~S}$ (Experimental points, Michaelis-Menten and Haldane models) (EBRT=63s; $\mathrm{C}_{\mathrm{Ln}}$ between 0.03 and $0.46 \mathrm{~g} \mathrm{~m}^{-3}$ ). 
Table 1: Composition of expanded schist.

\begin{tabular}{cc}
\hline Composition & \% \\
\hline $\mathrm{SiO}_{2}$ & 55.3 \\
$\mathrm{Al}_{2} \mathbf{O}_{3}$ & 20.2 \\
$\mathbf{F e}_{2} \mathbf{O}_{3}$ & 13.3 \\
$\mathbf{K}_{2} \mathbf{O}$ & 5.1 \\
$\mathrm{MnO}$ & 0.1 \\
$\mathrm{SO}_{3}$ & 1.5 \\
$\mathbf{P}_{2} \mathbf{O}_{5}$ & 1.9 \\
$\mathbf{C a O}$ & 1.2 \\
$\mathbf{T i O}_{2}$ & 1.1 \\
\hline
\end{tabular}


Table 2: Characteristics of expanded schist

\begin{tabular}{cc}
\hline Median pore diameter $(\mathbf{m m})$ & 12 \\
Porosity (\%) & 47 \\
Bulk density $\left(\mathrm{kg} \mathrm{m}^{-3}\right)$ & 667 \\
Apparent density $\left(\mathrm{kg} \mathrm{m}^{-3}\right)$ & 1248 \\
Specific surface area $\left(\mathrm{m}^{2} \mathbf{~ m}^{-3}\right)$ & 500 \\
\hline
\end{tabular}


Table 3: Operating conditions

\begin{tabular}{|c|c|c|c|c|}
\hline Phase & $\begin{array}{c}\text { Duration } \\
\text { (days) }\end{array}$ & $\begin{array}{c}{\left[\mathrm{H}_{2} \mathrm{~S}\right]} \\
(\mathrm{ppmv})\end{array}$ & $\begin{array}{c}\text { LR } \\
\left(\mathrm{g} \mathrm{m}^{-3} \mathrm{~h}^{-1}\right)\end{array}$ & $\begin{array}{c}Q_{\text {Liq }} \\
\left(\mathrm{L} \mathrm{day}^{-1}\right)\end{array}$ \\
\hline 1 & 10 & 40 & 3.2 & 12 \\
\hline 2 & 10 & 60 & 4.7 & 12 \\
\hline 3 & 20 & 80 & 6.3 & 12 \\
\hline 4 & 20 & 133 & 10.5 & 12 \\
\hline 5 & 112 & 250 & 19.8 & 12 \\
\hline 6 & 28 & 360 & 28.5 & 12 \\
\hline 7 & 58 & 250 & 19.8 & 120 \\
\hline 8 & 9 & 360 & 28.5 & 120 \\
\hline
\end{tabular}


Table 4: Biodegradation kinetics values determined from the Michaelis-Menten and Haldane models

\begin{tabular}{cc}
\hline Michaelis-Menten model & Haldane model \\
\hline $\mathrm{EC}_{\text {max }}=28.6 \mathrm{~g} \mathrm{~m}^{-3} \mathrm{~h}^{-1}$ & $\mathrm{EC}^{*}=33.3 \mathrm{~g} \mathrm{~m}^{-3} \mathrm{~h}^{-1}$ \\
$\mathrm{~K}_{\mathrm{s}}=0.070 \mathrm{~g} \mathrm{~m}^{-3}$ & $\mathbf{K}_{\mathrm{s}}^{*}=0.080 \mathrm{~g} \mathrm{~m}^{-3}$ \\
& $\mathrm{~K}_{\mathrm{I}}=1.53 \mathrm{~g} \mathrm{~m}^{-3}$ \\
$\mathrm{EC}_{\max }$ & $=22.7 \mathrm{~g} \mathrm{~m}^{-3} \mathrm{~h}^{-1}$ \\
\hline
\end{tabular}




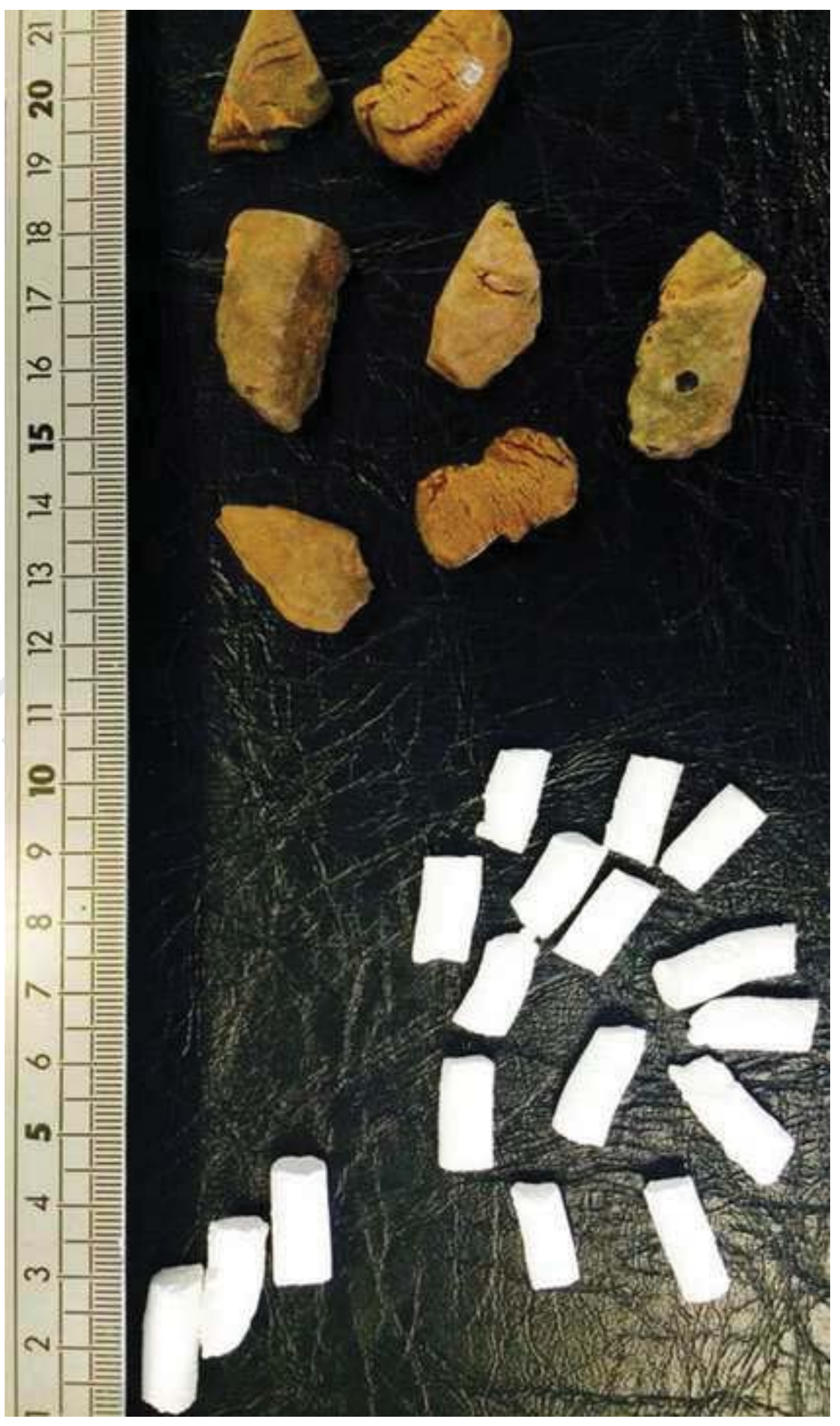



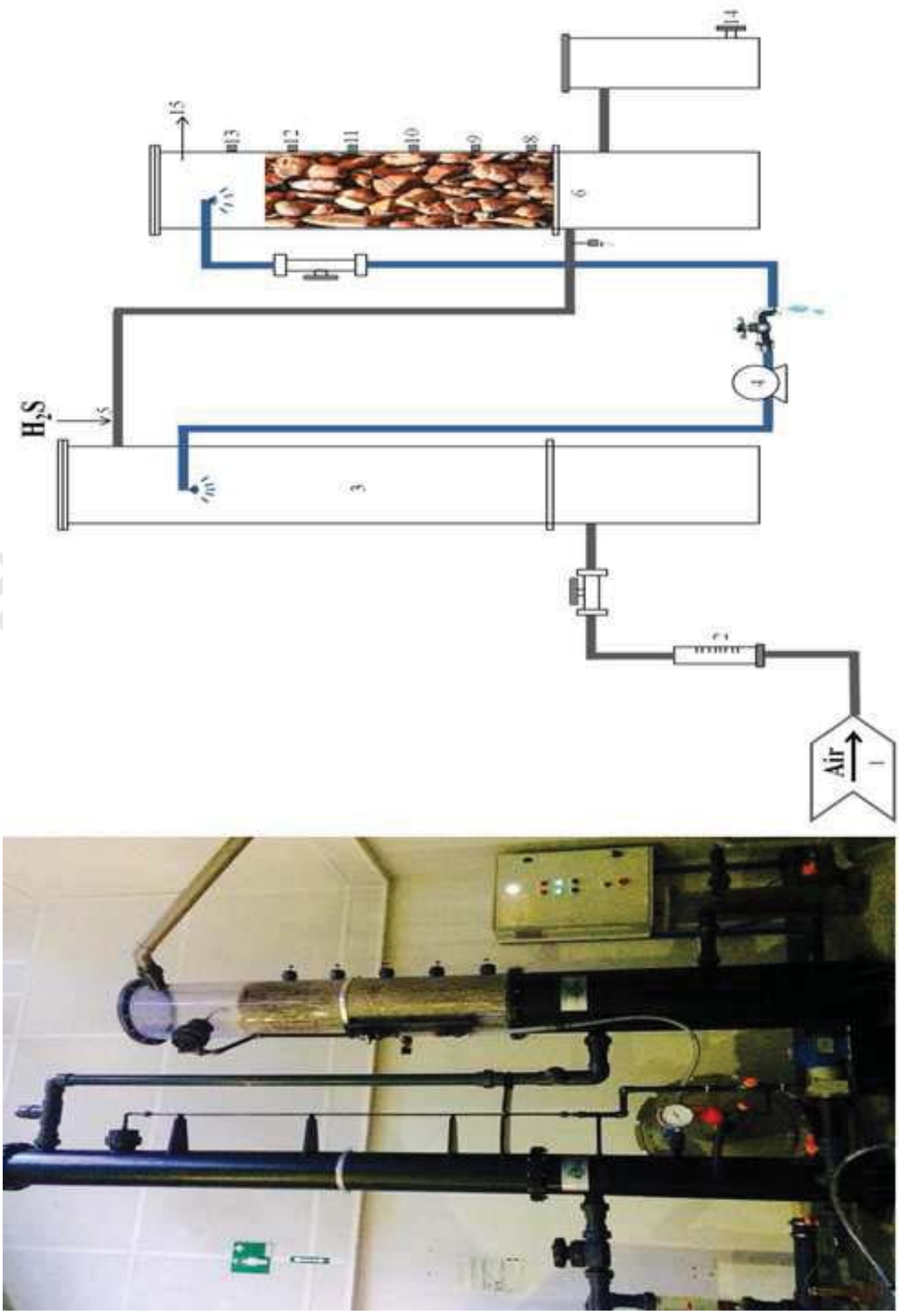


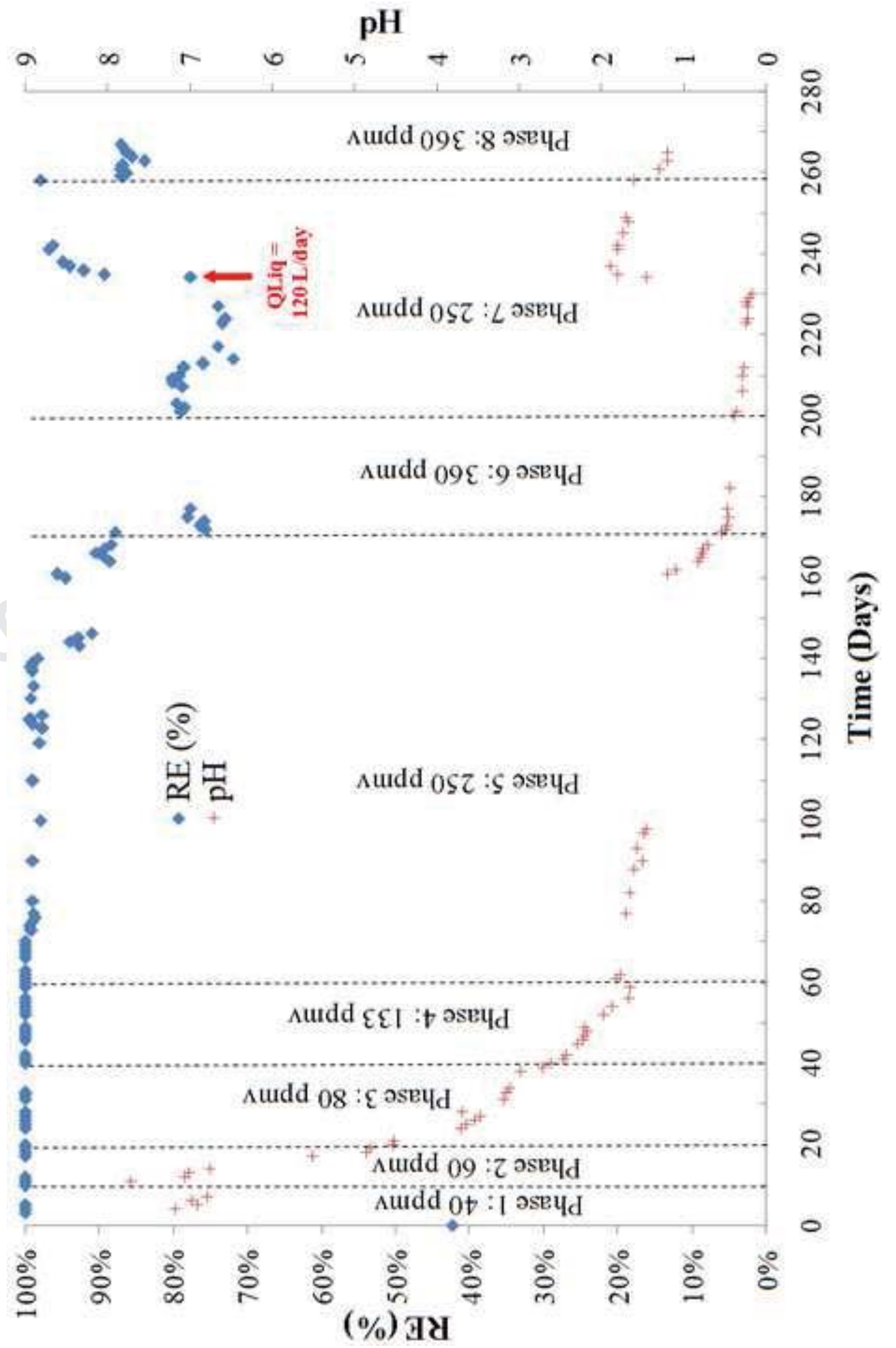




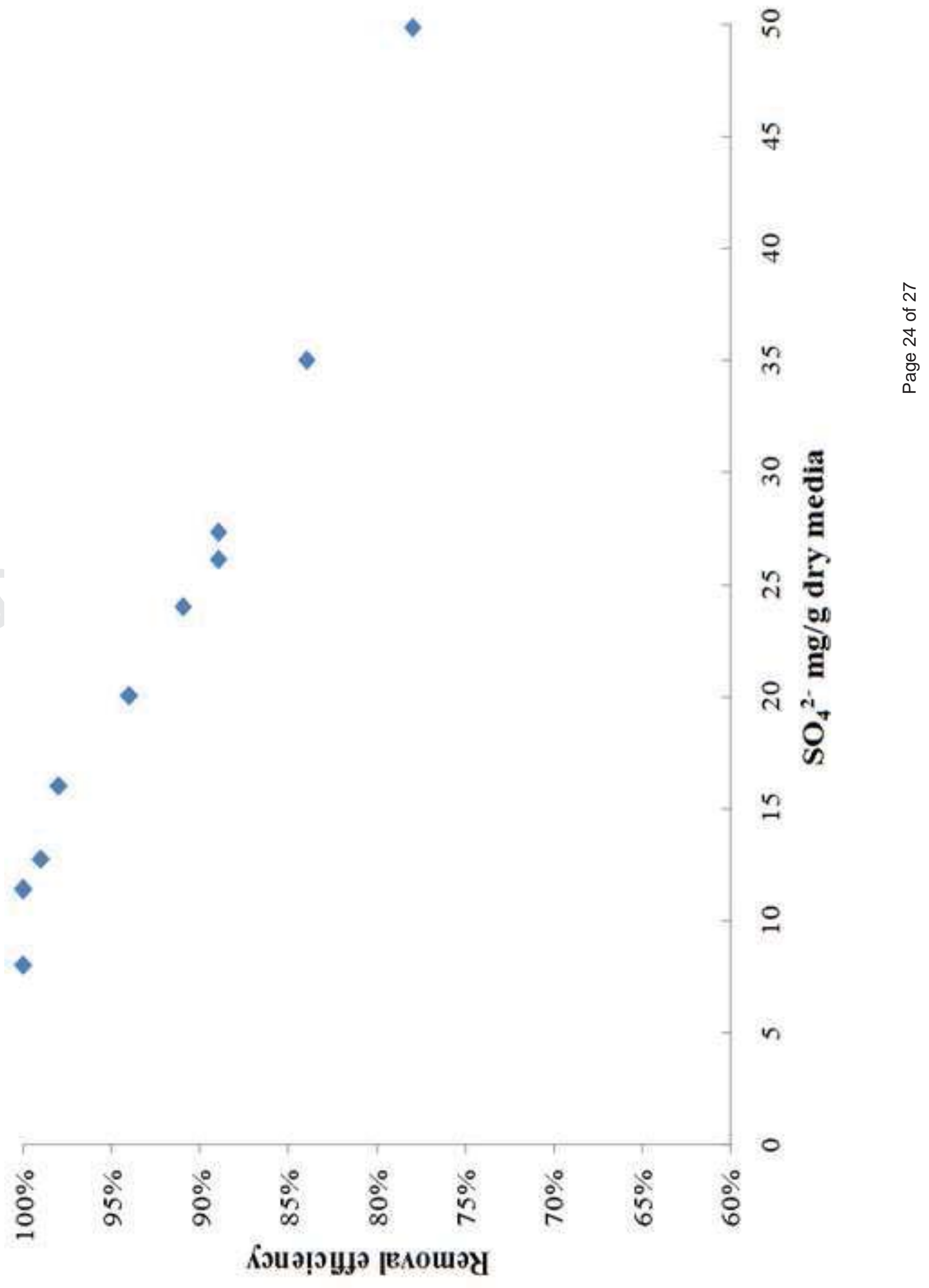

인 

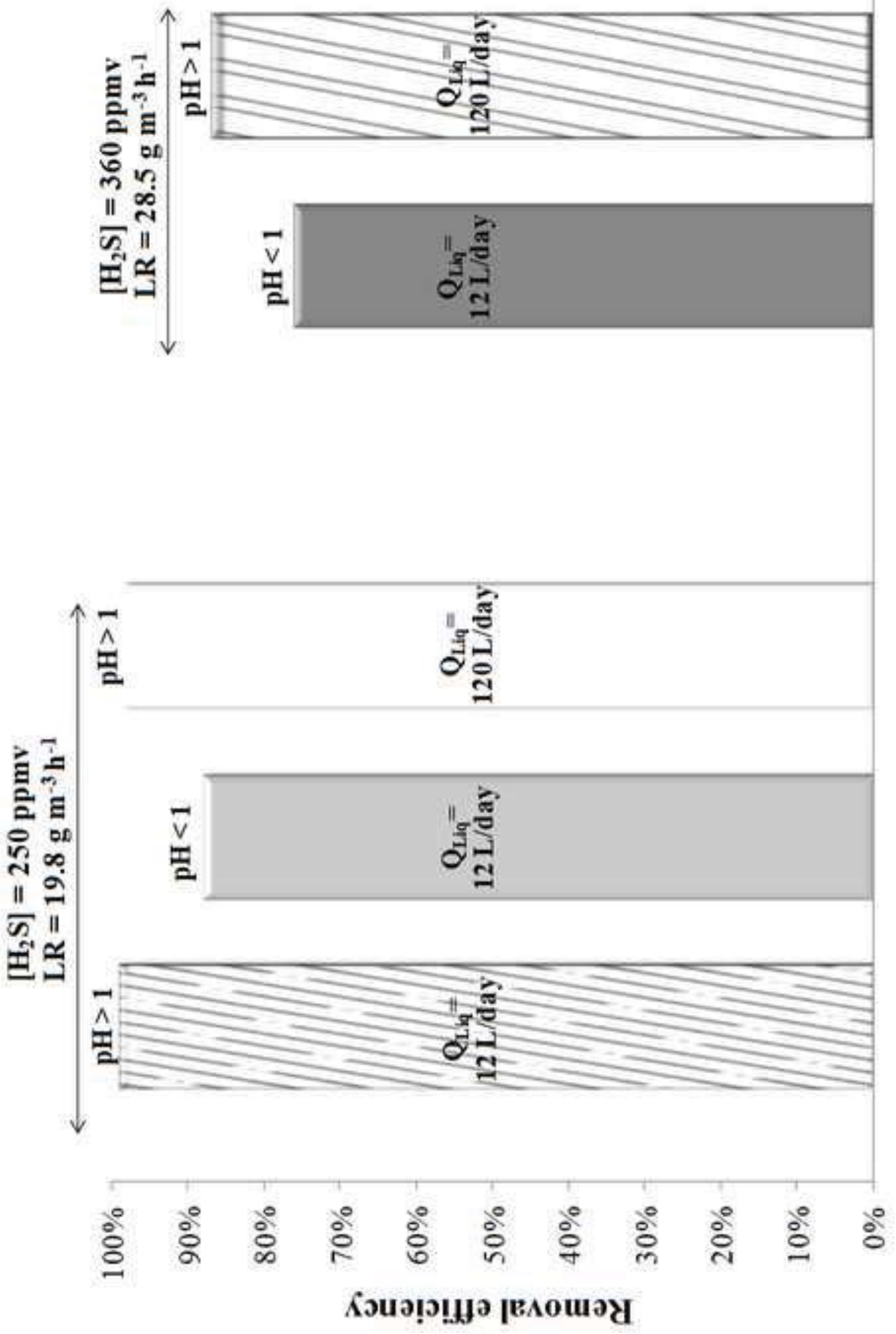


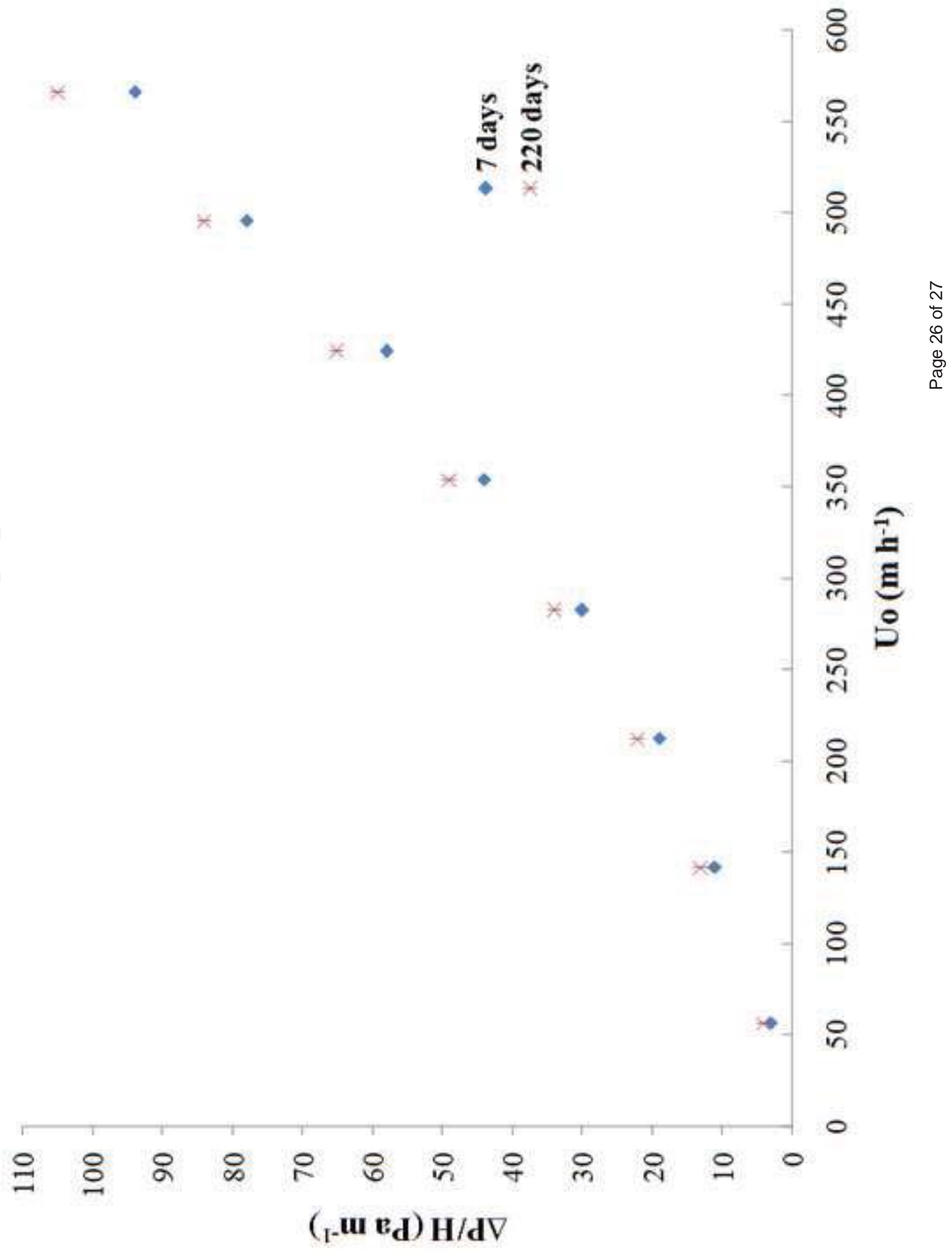

인 


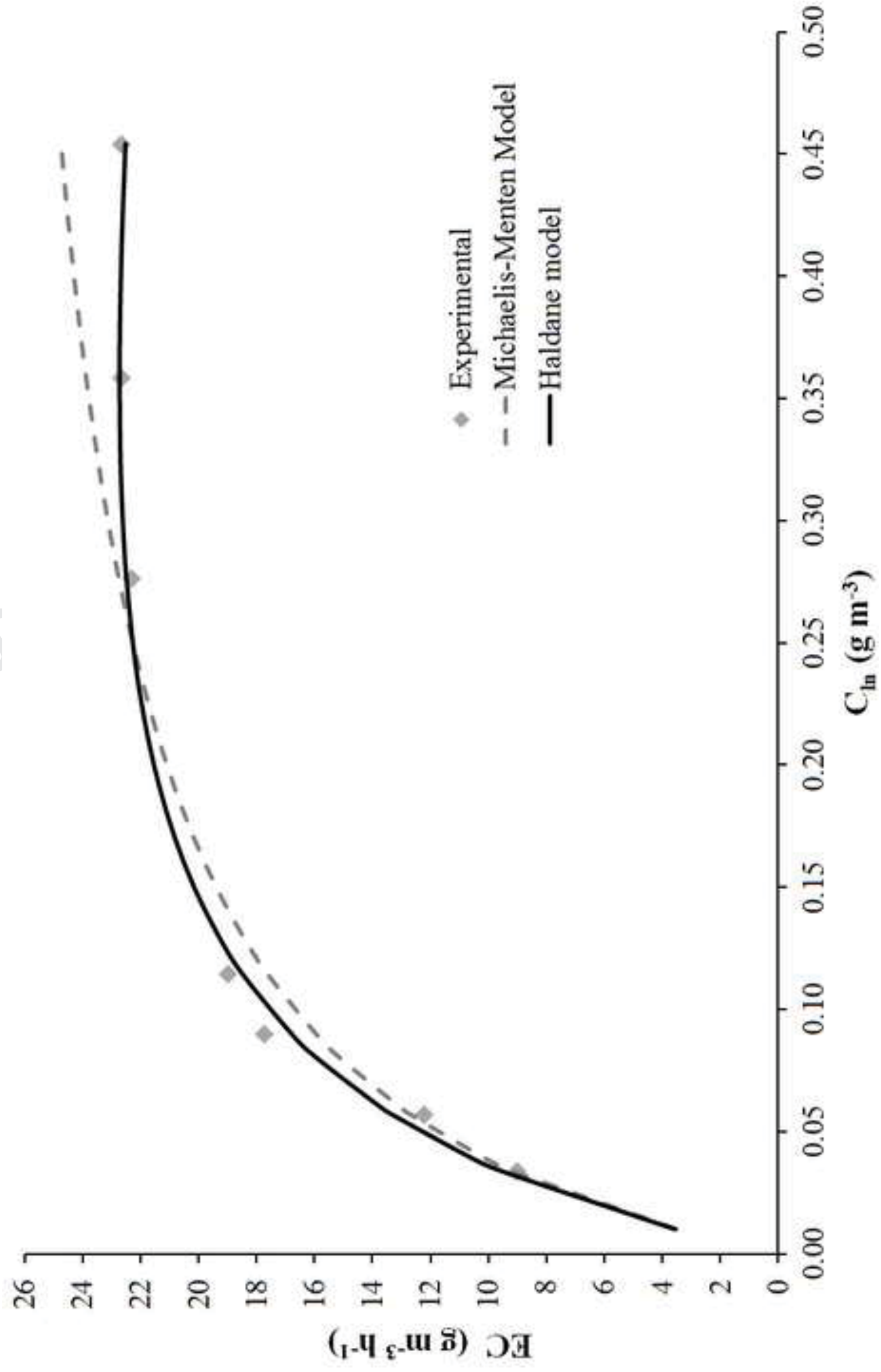

은 